\title{
Role of pH in Determining the Cell-type-specific Residual Activity of Glucocerebrosidase in Type 1 Gaucher Disease
}

S. van Weely, ${ }^{\star}$ M. van den Berg, ${ }^{\star}$ J. A. Barranger, ${ }^{\ddagger}$ M. C. Sa Miranda, ${ }^{5}$ J. M. Tager, ${ }^{\star}$ and J. M. F. G. Aerts *

${ }^{*}$ E. C. Slater Institute for Biochemical Research, University of Amsterdam, Academic Medical Centre, 1105 AZ Amsterdam, The Netherlands; ${ }^{\ddagger}$ Department of Human Genetics, University of Pittsburgh, Pittsburgh, Pennsylvania 15261; and ${ }^{\S}$ Instituto Genetica Medica Jacinto Magalhaes, 4000 Porto, Portugal

\section{Abstract}

The properties of control and ${ }^{370}$ Asn $\rightarrow$ Ser glucocerebrosidase, the frequently encountered mutated form of the enzyme in type 1 Gaucher disease, were studied in vitro as well as in situ.

The catalytic properties of purified ${ }^{370}$ Asn $\rightarrow$ Ser glucocerebrosidase were highly dependent on the assay conditions. The enzyme was deficient in activity towards substrate and in reactivity with the irreversible inhibitor conduritol B-epoxide (CBE) when activated by the bile salt taurocholate. In the presence of more physiological activators, the lysosomal activator protein saposin $\mathrm{C}$ and phosphatidylserine, the ${ }^{370} \mathrm{Asn} \rightarrow$ Ser enzyme was near normal in kinetic properties at $\mathbf{p H}$ values $\sim 5$, but not at higher $\mathrm{pH}$.

In intact fibroblasts, the enzymic activity of the ${ }^{370} \mathrm{Asn} \rightarrow$ Ser glucocerebrosidase and its reactivity with $\mathrm{CBE}$ were found to be clearly deficient. However, in intact lymphoblasts from the same patients, the behavior of the mutant enzyme was near normal. The catalytic efficiency of ${ }^{370} \mathrm{Asn} \rightarrow$ Ser glucocerebrosidase in situ was also found to be highly $\mathrm{pH}$ dependent. When intact lymphoblasts were cultured in the presence of permeant weak bases, which increase the $\mathrm{pH}$ of acidic intracellular compartments, the catalytic efficiency of the mutant enzyme, as assessed by its reactivity with CBE, became markedly impaired.

Our findings indicate that the intralysosomal pH in the intact cell can be expected to have a critical influence on the activation state of ${ }^{370} \mathrm{Asn} \rightarrow$ Ser glucocerebrosidase and its ability to hydrolyse substrate. This phenomenon may partly underly the marked heterogeneity in clinical manifestation of Gaucher disease among patients with this mutated form of glucocerebrosidase. (J. Clin. Invest. 1993. 91:1167-1175.) Key words: conduritol B-epoxide • glucosylceramide lipidosis • lysosomal storage disorder • saposin $\mathrm{C}$

\section{Introduction}

Gaucher disease (glucosylceramidosis) is a recessively inherited lysosomal storage disorder in which the activity of glucocerebrosidase (EC 3.2.1.45) is deficient. The clinical mani-

Address correspondence to J. M. F. G. Aerts, Publication Secretary, E. C. Slater Institute for Biochemical Research, University of Amsterdam, Academic Medical Centre, Meibergdreef 15, 1105 AZ Amsterdam, The Netherlands. 1992

Received for publication 26 May 1992 and in revised form 4 July

J. Clin. Invest.

(c) The American Society for Clinical Investigation, Inc.

0021-9738/93/03/1167/09 \$2.00

Volume 91, March 1993, 1167-1175 festation of the disease is very heterogeneous with respect to age of onset and neurological involvement. In patients with the most frequently encountered form, type 1 , the clinical presentation may vary from cases with severe splenomegaly and bone deterioration to cases without clear clinical complications (1). Type 2 and type 3 Gaucher disease patients develop neurological complications in infancy or childhood, respectively (1). Gaucher disease is genetically heterogeneous. Several mutations in glucocerebrosidase have been identified (2-6), and it has become clear that patients may have either two identical or, more generally, two different mutant glucocerebrosidase alleles (see e.g., references 7 and 8). Most type 1 Gaucher disease patients carry at least one copy of a mutant glucocerebrosidase allele in which a mutation at position 1,226 in the cDNA leads to substitution of $G$ for A (cDNA nucleotides are numbered starting with the upstream ATG at number 1 [9]). This results in a substitution of serine for asparagine at amino acid position 370 in the mature protein $(8,10,11)$. The ${ }^{370}$ Asn $\rightarrow$ Ser glucocerebrosidase is present in normal amounts (12-15). In vitro, this enzyme is only poorly active under most conditions; however, when activated at acidic $\mathrm{pH}$ by negatively charged phospholipid and the natural lysosomal activator protein saposin C, formerly referred to as sphingolipid activator protein 2 (for a review, see reference 16), its activity is near normal (17). Another frequently encountered form of mutated glucocerebrosidase has a $\mathrm{C}$ for $\mathrm{T}$ substitution at nucleotide position 1,448 , resulting in a proline for leucine substitution at position 444 in the mature protein. This mutation has been detected in various phenotypes of Gaucher disease. Most patients who are homozygous for this mutation develop a neuronopathic course of the disease $(7,11,18-20)$. The ${ }^{444}$ Leu $\rightarrow$ Pro glucocerebrosidase results in reduced enzyme stability (15-21). In a third commonly encountered allele, a $\mathrm{G}$ insertion in the glucocerebrosidase gene at cDNA position 84 results in production of a truncated protein (22).

The consequences of the ${ }^{370}$ Asn $\rightarrow$ Ser substitution for catalytic efficiency of glucocerebrosidase in situ are not yet fully understood. It has previously been observed by us that the state of activation of ${ }^{370}$ Asn $\rightarrow$ Ser glucocerebrosidase, and concomitantly its catalytic efficiency, differs in homogenates of fibroblasts and lymphoblasts obtained from the same type 1 Gaucher disease patients (23). We have now studied the properties of glucocerebrosidase in intact fibroblasts and lymphoblasts. First, the degradation of a fluorescent analogue of glucocerebroside by intact cells was measured. Second, the reactivity of glucocerebrosidase with the irreversible inhibitor conduritol B-epoxide $(\mathrm{CBE})^{1}$ was assessed. This inhibitor is analogous in

1. Abbreviations used in this paper: $\mathrm{CBE}$, conduritol B-epoxide; $\mathrm{C}_{6}$ NBD glucosylceramide, 6-[ $N$-7-nitrobenz-2-oxa-1,3 diazol-4-yl-aminocaproyl] sphingosyl $\beta$-D-glucoside; 4 -MU- $\beta$-glucoside, 4 -methylumbelliferyl- $\beta$-D-glucoside. 
structure to the transition state of gluconolactone formed during hydrolysis of glucocerebroside. In contrast to the natural transition state compound, the epoxide is able to form a covalent bond with an aspartic acid group in the catalytic site, thus irreversibly inhibiting the enzyme $(2,24)$. It has elegantly been shown by Bieberich and Legler (25) that CBE rapidly enters lysosomes in intact cells and effectively inhibits the enzyme in situ.

Our investigation revealed differences between properties of glucocerebrosidase in intact fibroblasts and in intact lymphoblasts from type 1 Gaucher disease patients with ${ }^{370}$ Asn $\rightarrow$ Ser glucocerebrosidase. The possible role of the natural activator protein saposin $\mathrm{C}$ and lysosomal $\mathrm{pH}$ in this connection was investigated. The results are reported here, and the implications are discussed.

\section{Methods}

Materials. CBE was purchased from Biomol Research Laboratories (Philadelphia, PA), sodium taurocholate grade A was purchased from Calbiochem (San Diego, CA); and phosphatidylserine, and 4-methylumbelliferyl- $\beta$-D-glucoside (4-MU- $\beta$-glucoside) was purchased from Sigma Immunochemicals (St. Louis, MO). $\mathrm{C}_{6}$-NBD glucosylceramide (6-[ $N$-7-nitrobenz-2-oxa-1,3 diazol-4-yl-aminocaproyl] sphingosyl $\beta$ D-glucoside) was a kind gift from Dr. G. Schwarzmann (University of Bonn, Bonn, Germany). All other chemicals were of the purest grade commercially available.

Cell lines of Gaucher disease patients. Properties of glucocerebrosidase were studied in cultured skin fibroblasts and EBV transformed B lymphocytes (lymphoblasts) from Gaucher disease patients with a defined glucocerebrosidase genotype; i.e. genotypes ${ }^{370} \mathrm{Asn} \rightarrow \mathrm{Ser} /{ }^{370} \mathrm{Asn}$ $\rightarrow$ Ser, ${ }^{444}$ Leu $\rightarrow$ Pro $/{ }^{444}$ Leu $\rightarrow$ Pro and ${ }^{370}$ Asn $\rightarrow$ Ser $/{ }^{444}$ Leu $\rightarrow$ Pro. Fibroblasts were obtained by skin biopsies and lymphoblasts were obtained by transformation of peripheral blood B lymphocytes with EBV $(23,26)$. The cells were cultured in RPMI 1640 containing $10 \%$ (by volume) FCS and bicarbonate with $5 \% \mathrm{CO}_{2}$ in the gas phase. The glucocerebrosidase genotype of the patients was determined by allelespecific oligonucleotide hybridization (26). In the case of patient $C$ (Table I), it has not as yet been excluded that the mutated ${ }^{444}$ Leu $\rightarrow$ Pro allele contains additional mutations (also referred to as complex pattern alleles). The cell biological consequences of the ${ }^{444} \mathrm{Leu} \rightarrow$ Pro mutation and one of the complex pattern alleles are known to be similar; i.e. the production of a rapidly degraded glucocerebrosidase (15).

The Gaucher disease patients homozygous or heterozygous for the ${ }^{370}$ Asn $\rightarrow$ Ser allele varied markedly in severity of nonneuronopathic manifestation of the disorder. The patients homozygous for the ${ }^{444} \mathrm{Leu}$ $\rightarrow$ Pro allele had developed neurological complications already in infancy (type 2) or only in childhood (type 3 ).

Consistent with earlier findings, it was noted using PAGE in the presence of sodium dodecyl sulphate followed by Western blotting (27), that the amount of glucocerebrosidase antigen was normal in fibroblasts of patients homozygous for the ${ }^{370}$ Asn $\rightarrow$ Ser allele (i.e., type 1 patients) and very strongly reduced in fibroblasts of patients homozygous for the ${ }^{444}$ Leu $\rightarrow$ Pro allele (i.e., type 2 and 3 patients). In cells from patients who were genetic compounds carrying both alleles, intermediate amounts of cross-reactive glucocerebrosidase were detected.

Preparation of antisera. A monospecific rabbit antiserum to human placental glucocerebrosidase was prepared as described (28). A monospecific rabbit antiserum to saposin $\mathrm{C}$ was prepared as described (29).

Immunoaffinity chromatographic purification of glucocerebrosidase. Glucocerebrosidase was purified from various materials by immunoaffinity chromatography with immobilized antiglucocerebrosidase monoclonal antibodies $8 \mathrm{E} 4$ and $2 \mathrm{C} 7$ as immunosorbens exactly as described previously (30).
Table I. Relative Specific Activity of Glucocerebrosidase Immunopurified from Cultured Skin Fibroblasts of Gaucher Patients

\begin{tabular}{lccc}
\hline & & \multicolumn{2}{c}{$\begin{array}{c}\text { Relative specific activity measured in the } \\
\text { presence of }\end{array}$} \\
\cline { 3 - 4 } Genotype & Patient & Taurocholate/Triton & PS/saposin C \\
\hline & & $\%$ & $\%$ \\
$370 / 370$ & $\mathrm{~A}$ & 16,14 & 77,88 \\
$370 / 444$ & $\mathrm{~B}$ & 15,8 & 79,84 \\
& $\mathrm{C}$ & 21,20 & 92,87 \\
$444 / 444$ & $\mathrm{D}$ & 22 & 89 \\
& E & 81,73 & 86,82 \\
Control $(n=4)$ & $\mathrm{F}$ & 85 & 81 \\
& & $88-115$ & $92-107$ \\
\hline
\end{tabular}

Identical amounts of cross-reactive glucocerebrosidase in preparations from cultured skin fibroblasts of control subjects and Gaucher disease patients were bound in a microtiter plate in which monoclonal antihuman glucocerebrosidase antibody $8 \mathrm{E} 4$ was immobilised, as described in Methods. The relative specific activity is the enzymic activity per amount of cross-reactive glucocerebrosidase in a preparation from a cell line of a Gaucher disease patient as percentage of the mean value for preparations from four different control fibroblast cell lines. The activity of bound glucocerebrosidase was determined with two different assay mixtures, each well containing $150 \mu$ l assay mixture. The reaction was stopped by addition of $100 \mu \mathrm{l} 1 \mathrm{M}$ glycine- $\mathrm{NaOH}, \mathrm{pH}$ 10.6. The taurocholate/Triton assay mixture contained $5 \mathrm{mM} 4-\mathrm{MU}-\beta$-glucoside, $0.1 \%$ (by volume) Triton X-100, $0.5 \%$ (mass/vol) sodium taurocholate, $100: 200 \mathrm{mM}$ citric acid/sodium phosphate, $\mathrm{pH} 5.0$; and the phosphatidylserine/saposin $\mathrm{C}$ assay mixture contained $5 \mathrm{mM} 4-\mathrm{MU}-\beta$-glucoside, $10 \mu \mathrm{g} / \mathrm{ml}$ phosphatidylserine, $2.4 \mu \mathrm{g} / \mathrm{ml}$ saposin $\mathrm{C}$ preparation, $100: 200 \mathrm{mM}$ citric acid/sodium phosphate, pH 5.0. The specific activity of control glucocerebrosidase immobilized to monoclonal antibody $8 \mathrm{E} 4$ was 1.8 and 1.4 $\mathrm{nmol} / \mathrm{h}$ per $\mathrm{mg}$ protein when measured in the presence of taurocholate/Triton and PS/saposin C, respectively. $370,{ }^{370}$ Asn $\rightarrow$ Ser allele; $444,{ }^{444}$ Leu $\rightarrow$ Pro allele.

Purification of saposin $C$. The activator protein was purified according to the procedure described (31).

Assessment of activator protein level. The level of activator protein was determined by a functional test as described (12).

The assay of glucocerebrosidase with 4-MU-B-glucoside as substrate. Fibroblasts were harvested by trypsinisation and lymphoblasts by centrifugation. The cells were washed in isotonic PBS and homogenized as indicated in the text. The contribution of lysosomal glucocerebrosidase to the total $\beta$-glucosidase activity was determined using CBE. Enzyme preparations were simultaneously preincubated for $5 \mathrm{~min}$ without $\mathrm{CBE}$, or with $5 \mathrm{mM} \mathrm{CBE}$ to ensure that all glucocerebrosidase was inactivated by the irreversible inhibitor, and subsequently $\beta$-glucosidase activity was measured in the absence and presence of $1 \mathrm{mM} \mathrm{CBE}$ under the conditions indicated in the text. The CBE-inhibitable $\beta$-glucosidase activity is caused by the lysosomal glucocerebrosidase (31). Protein was determined as described by Lowry et al. (32) with BSA as standard.

Measurement of relative specific activity of glucocerebrosidase. Previous studies have shown that monoclonal anti-(human glucocerebrosidase) antibody $8 \mathrm{E} 4$ has the same binding affinity for control, ${ }^{370} \mathrm{Asn}$ $\rightarrow$ Ser substituted and ${ }^{444}$ Leu $\rightarrow$ Pro substituted glucocerebrosidase $(12,13,15)$. Thus, identical amounts of various types of glucocerebrosidase will be bound to a specific amount of immobilized monoclonal antibody 8E4 when the immunosorbens is saturated by incubation with an excess of an enzyme preparation. If the enzyme preparation 
consists of a mixture of two forms of glucocerebrosidase, the bound glucocerebrosidase will be a comparable mixture. These binding characteristics of the monoclonal antibody 8E4 allow a simple analysis of the specific activity of mutated glucocerebrosidase per amount of enzyme protein as described previously (12). Briefly, identical amounts of antiglucocerebrosidase monoclonal antibody $8 \mathrm{E} 4$ were immobilized to wells of a microtiter plate. The wells were incubated with enzyme preparations containing an excess of glucocerebrosidase antigen. The activity of bound glucocerebrosidase was measured with the fluorogenic 4-MU- $\beta$-glucoside as substrate as described in the legend of Table I. Fluorescence in the wells of the microtiter plate was determined (Fluoroscan; Flow Laboratories Inc., McLean, VA) with excitation at $366 \mathrm{~nm}$ and emission at $450 \mathrm{~nm}$.

Measurement of hydrolysis of $C_{6}-N B D$ glucosylceramide in intact cells. $\mathrm{C}_{6}$-NBD glucosylceramide was complexed with $\mathrm{BSA}$ as described (13). Cells were incubated for $24 \mathrm{~h}$ at $37^{\circ} \mathrm{C}$ with $5 \mu \mathrm{M}$ lipid-BSA complex in the absence or presence of excess $\mathrm{CBE}$. The cells were harvested, and lipids were extracted and separated by thin layer chromatography. The fluorescent lipids were scraped off, extracted, and quantified fluorimetrically as described (13).

Immuno-electron microscopy. Cultured human skin fibroblasts and EBV-lymphoblasts were fixed and prepared for immunogold labeling and electron microscopy following the procedure described for fibroblasts (33). Frozen cell samples were cryosectioned and immunolabeled, and examined using a transmission electron microscope (model 300; Phillips Electronic Instruments Co., Mahwah, NJ) at an accelerating voltage of $60 \mathrm{kV}$.

\section{Results}

\section{Enzymic properties of purified glucocerebrosidase}

Glucocerebrosidase was purified by immunoaffinity chromatography from cultured skin fibroblasts. The recovery of enzyme in monomeric form (31) was always $>70 \%$ on the basis of enzymic activity as measured in the presence of taurocholate.

Relative specific aciivity. The enzymic activity per amount of cross-reactive glucocerebrosidase related to that of control enzyme (i.e., the relative specific activity) was determined for enzyme preparations from fibroblasts from various types of Gaucher disease patients (see Table I). When measured in the presence of taurocholate and Triton X-100, the relative specific activity of glucocerebrosidase in preparations of cells of patients homozygous for the ${ }^{370} \mathrm{Asn} \rightarrow$ Ser allele is abnormally low, and that of enzyme in preparations from cells of patients homozygous for the ${ }^{444} \mathrm{Leu} \rightarrow$ Pro allele is close to normal. The relative specific activity of glucocerebrosidase in preparations from cells of patients who are genetic compounds for the ${ }^{370}$ Asn $\rightarrow$ Ser and ${ }^{444}$ Leu $\rightarrow$ Pro alleles is also low, suggesting that they contain predominantly ${ }^{370}$ Asn $\rightarrow$ Ser glucocerebrosidase molecules.

When bound glucocerebrosidase is measured in the presence of phosphatidylserine and activator protein the relative specific activity of enzyme in the preparations from fibroblasts of all the patients is near normal (see Table I). In other words, under these conditions, the ${ }^{370} \mathrm{Asn} \rightarrow$ Ser glucocerebrosidase is normalized.

The amount of cross-reactive glucocerebrosidase can be estimated by comparing the data for relative specific activity with values for specific activity in the corresponding cell extracts. In this way, it was calculated that the concentration of glucocerebrosidase antigen is $80-100 \%$ in fibroblasts from patients with genotype ${ }^{370}$ Asn $\rightarrow$ Ser $/{ }^{370}$ Asn $\rightarrow$ Ser, $<10 \%$ in cells from patients with genotype ${ }^{444}$ Leu $\rightarrow$ Pro $/{ }^{444}$ Leu $\rightarrow$ Pro and $\sim 30 \%$ in cells from patients carrying both alleles.

Inactivation by $C B E$. The irreversible inhibition of glucocerebrosidase by CBE was determined for enzyme purified from fibroblasts of individuals with different glucocerebrosidase genotypes. Fig. $1 A$ shows the results when enzyme preparations were incubated with inhibitor in the presence of taurocholate and Triton X-100, and enzyme activity was subsequently determined under the same conditions. The glucocerebrosidase purified from fibroblasts of the patient homozygous for the ${ }^{444} \mathrm{Leu} \rightarrow$ Pro allele was inactivated in a manner similar to control enzyme, but the inactivation of enzyme purified from cells of the patient homozygous for the ${ }^{370}$ Asn $\rightarrow$ Ser allele was very slow. The inactivation of enzyme purified from cells of the genetic compound proceeded with intermediate kinetics. When the enzyme preparations were incubated with inhibitor in the presence of phosphatidylserine and activator protein at $\mathrm{pH} 5.0$, and the enzyme activity was determined under the same condition a different picture was obtained (see Fig. $1 \mathrm{~B}$ ). Under these conditions, the behavior of glucocerebrosidase purified from fibroblasts of all the Gaucher disease patients was not clearly different from that of control enzyme. This suggests that in the presence of phospholipid and activator protein the ${ }^{370} \mathrm{Asn} \rightarrow$ Ser glucocerebrosidase is not only 'normalized' in activity towards substrate, but also in reactivity with CBE.

Analogous findings to the results presented in Table I and Fig. 1 were made for glucocerebrosidase purified from urine samples, spleens, and lymphoblasts from type 1 Gaucher disease patients (not shown). No significant differences were ob-

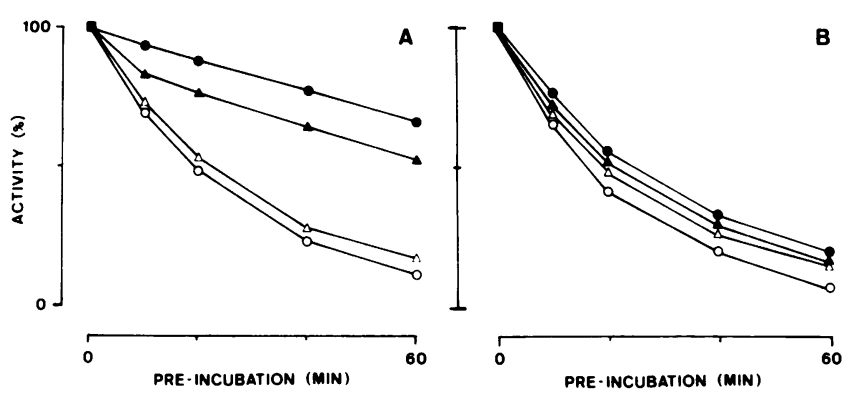

Figure 1. Inactivation of purified glucocerebrosidase by conduritol B-epoxide. Glucocerebrosidase was purified from fibroblasts of individuals with known glucocerebrosidase genotype by immunoaffinity chromatography as described previously (30). The purified enzyme was preincubated at room temperature for the times indicated with $25 \mu \mathrm{M} \mathrm{CBE}$ in 100:200 mM citric acid/sodium phosphate buffer, $\mathrm{pH}$ 5.0 , containing $0.1 \%$ (mass $/ \mathrm{vol}$ ) BSA and $10 \%$ (by volume) ethylene glycol. The preincubation mixture furthermore contained either $0.1 \%$ (by volume) Triton $\mathrm{X}-100$ and $0.5 \%$ (mass/vol) sodium taurocholate $(A)$ or $10 \mu \mathrm{g} / \mathrm{ml}$ phosphatidylserine and $2.4 \mu \mathrm{g} / \mathrm{ml}$ saposin $C$ preparation $(B)$. Subsequently, the enzyme preparation was diluted 10 -fold in preincubation mixture from which CBE was omitted and to which $5 \mathrm{mM}$ 4-MU- $\beta$-glucoside was added. The activity is expressed as a percentage of that found without preincubation. The results of a typical experiment are shown. Similar results were obtained in three to five other experiments and with different batches of CBE. The values in parentheses indicate the specific activity of immunopurified glucocerebrosidase (nanomoles per hour per milligram of protein) in the presence of taurocholate/Triton X-100. $\circ$, Control (2.8); $\bullet,{ }^{370} \mathrm{Asn}$ $\rightarrow$ Ser $/{ }^{370}$ Asn $\rightarrow \operatorname{Ser}(0.21) ; \triangle,{ }^{370}$ Asn $\rightarrow$ Ser $/{ }^{444}$ Leu $\rightarrow$ Pro $(0.31)$; $\Delta,{ }^{444}$ Leu $\rightarrow$ Pro $/{ }^{444}$ Leu $\rightarrow$ Pro $(2.0)$. 
served between enzyme preparations from the various sources examined.

It is of importance to note that the reactivity of glucocerebrosidase with CBE is to some extent a good reflection of the activity of the enzyme towards substrate. This was also observed when membrane suspensions were tested instead of pure enzyme preparations.

\section{Enzymic properties of glucocerebrosidase in intact fibroblasts and lymphoblasts}

Activity towards substrate. The glucocerebrosidase activity in cultured fibroblasts and lymphoblasts from type 1 Gaucher disease patients and control subjects was determined by loading cells with $\mathrm{C}_{6}$-NBD glucosylceramide as described in Methods. Recently we established the existence of a nonlysosomal glucocerebrosidase activity in cells that is insensitive to CBE. The properties of the nonlysosomal glucocerebrosidase, which is not deficient in Gaucher disease materials, are to be described in a separate publication. To allow discrimination between the lysosomal (CBE-sensitive) and nonlysosomal (CBEinsensitive) glucocerebrosidase cells were pretreated with and without an excess of CBE. The lysosomal glucocerebrosidase activity was determined as the CBE-inhibitable hydrolysis of $\mathrm{C}_{6}$-NBD glucosylceramide ( Table II). The residual activity in fibroblasts of patients with the ${ }^{370} \mathrm{Asn} \rightarrow$ Ser allele was always less than that in lymphoblasts from the same patients.

Inactivation by $C B E$. The kinetics of the irreversible inhibition of glucocerebrosidase upon incubation of intact cells with CBE was examined (Fig. 2). Glucocerebrosidase in control fibroblasts and in ${ }^{444}$ Leu $\rightarrow$ Pro $/{ }^{444}$ Leu $\rightarrow$ Pro fibroblasts was clearly inactivated more rapidly than the enzyme in ${ }^{370}$ Asn $\rightarrow$ Ser $/{ }^{370}$ Asn $\rightarrow$ Ser fibroblasts when enzyme activity was subsequently measured either in the presence of taurocholate and Triton X-100 (Fig. $2 A$ ) or in the presence of phosphatidylserine and activator protein at acid pH (Fig. $2 \mathrm{~B}$ ). In ${ }^{370}$ Asn $\rightarrow$ $\mathrm{Ser} /{ }^{444} \mathrm{Leu} \rightarrow$ Pro fibroblasts, the inactivation of glucocerebrosidase appeared to be more rapid when the activity was subsequently measured in the presence of taurocholate and Triton

Table II. Glucocerebrosidase Activity In Situ towards $C_{6}-N B D$ Glucosylceramide in Fibroblasts and Lymphoblasts from a Control Subject and a Type 1 Gaucher Disease Patient

\begin{tabular}{|c|c|c|c|c|c|c|}
\hline \multirow[b]{3}{*}{ Cells from } & \multicolumn{6}{|c|}{$\begin{array}{l}\text { Percent conversion of } \mathrm{C}_{6}-\mathrm{NBD} \text { glucosylceramide } \\
\text { to ceramide }+ \text { sphingomyelin in }\end{array}$} \\
\hline & \multicolumn{3}{|c|}{ Fibroblasts } & \multicolumn{3}{|c|}{ Lymphoblasts } \\
\hline & $-\mathrm{CBE}$ & $+\mathrm{CBE}$ & $\begin{array}{c}\text { CBE- } \\
\text { Inhibitable }\end{array}$ & $-\mathrm{CBE}$ & $+\mathrm{CBE}$ & $\begin{array}{l}\text { CBE- } \\
\text { Inhibitable }\end{array}$ \\
\hline Control subject & 60 & 21 & 39 & 26 & 13 & 13 \\
\hline Gaucher patient & 35 & 29 & 6 & 21 & 12 & 9 \\
\hline
\end{tabular}

Cells grown in RPMI 1640 culture medium with $5 \% \mathrm{CO}_{2}$ in the gas phase were preincubated with or without $100 \mu \mathrm{M} \mathrm{CBE}$ for $24 \mathrm{~h}$ at $37^{\circ} \mathrm{C}$. Next, $\mathrm{C}_{6}$-NBD glucosylceramide/BSA $(5 \mu \mathrm{M}: 5 \mu \mathrm{M})$ was added. After $24 \mathrm{~h}$ at $37^{\circ} \mathrm{C}$, the cells were extensively washed and the NBD-lipids were extracted and analysed using thin layer chromatography as described in Methods. Glucocerebrosidase activity is expressed as the percent conversion of $\mathrm{C}_{6}-\mathrm{NBD}$ glucosylceramide to $\mathrm{C}_{6}-$ NBD ceramide and $\mathrm{C}_{6}$-NBD sphingomyelin. Fluorescence in other lipids was always $<4 \%$. Results of one experiment are shown; similar results were obtained in two independent experiments.

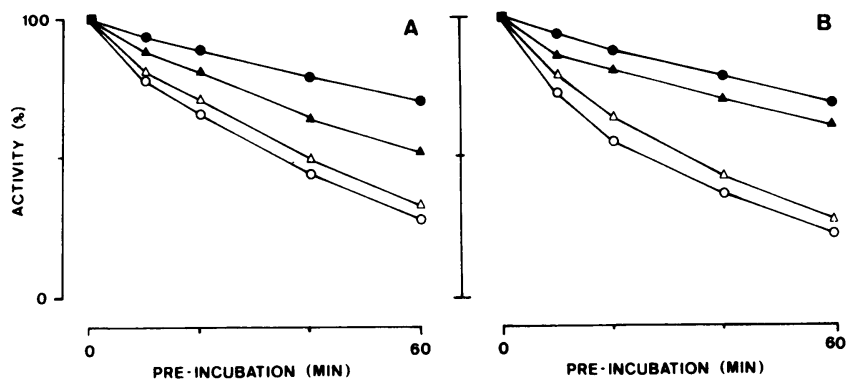

Figure 2. Inactivation of glucocerebrosidase in intact fibroblasts by conduritol B-epoxide. Cells were preincubated in culture medium for different periods of time with $100 \mu \mathrm{M} \mathrm{CBE}$. After harvesting and washing with PBS, the fibroblasts were homogenized in $50 \mathrm{mM}$ potassium phosphate, $\mathrm{pH} 6.5$, containing $0.25 \%$ (by volume) Triton $\mathrm{X}-100$. $\beta$-Glucosidase activity was determined with $5 \mathrm{mM} 4-\mathrm{MU}-\beta$ glucoside as substrate either in 100:200 mM citric acid/sodium phosphate, $\mathrm{pH} 5.2,0.1 \%$ (by volume) Triton $\mathrm{X}-100$ and $0.2 \%$ (mass/vol) sodium taurocholate $(A)$ or in 100:200 mM citric acid/sodium phosphate, $\mathrm{pH} 5.0,10 \mu \mathrm{g} / \mathrm{ml}$ phosphatidylserine, and $2.4 \mu \mathrm{g} / \mathrm{ml}$ saposin $C$ preparation $(B)$. The results of a typical experiment are indicated. Similar data were obtained in at least two independent experiments. $\bigcirc$, Control; $\bullet,{ }^{370}$ Asn $\rightarrow$ Ser $/{ }^{370}$ Asn $\rightarrow$ Ser; $\triangle$, ${ }^{370}$ Asn $\rightarrow$ Ser $/{ }^{444}$ Leu $\rightarrow$ Pro; $\Delta,{ }^{444}$ Leu $\rightarrow$ Pro $/{ }^{444}$ Leu $\rightarrow$ Pro.

$\mathrm{X}-100$ (Fig. $2 A$ ) than when it was measured with phosphatidylserine and activator protein (Fig. $2 B$ ). This apparent discrepancy results from the fact that with activator protein and phosphatidylserine, one measures predominantly ${ }^{370}$ Asn $\rightarrow$ Ser enzyme, which is slowly inactivated, whereas in the presence of taurocholate and Triton X-100, ${ }^{444}$ Leu $\rightarrow$ Pro enzyme contributes significantly to the total activity.

Comparison of different cell types. Cultured fibroblasts and lymphoblasts were incubated with CBE for different periods of time, and subsequently, enzymic activity of glucocerebrosidase was measured in the presence of taurocholate and Triton $\mathrm{X}-100$.

Table III shows again that lysosomal glucocerebrosidase in intact fibroblasts from patients with the ${ }^{370}$ Asn $\rightarrow$ Ser allele was clearly less sensitive to inhibition by $\mathrm{CBE}$ compared to enzyme in corresponding cells of a control subject and a patient homozygous for the ${ }^{444}$ Leu $\rightarrow$ Pro glucocerebrosidase allele. However, glucocerebrosidase in cultured lymphoblasts from a control subject, a patient homozygous for the codon 370 substitution, and a patient with both the codon 370 and codon 444 substitutions was comparably inactivated by CBE. This celltype-specific difference between fibroblasts and lymphoblasts was also observed in three type 1 Gaucher disease patients with one allele with the codon 370 mutation and an as yet unidentified mutated allele (not shown).

\section{Immunocytochemical analysis of glucocerebrosidase and activator protein saposin $C$ in cultured cells}

The apparent difference in glucocerebrosidase activity in intact lymphoblasts and fibroblasts could, in principle, be caused by a relatively higher concentration of activator protein in lysosomes of lymphoblasts. To test this possibility, the relative intralysosomal concentrations of glucocerebrosidase and activator protein in fibroblasts and lymphoblasts were studied by immunoelectron microscopy using specific antisera. Fig. 3 shows some examples of double-labeling of glucocerebrosidase and saposin in lysosomes in fibroblasts and lymphoblasts from 
Table III. Inactivation of Glucocerebrosidase in Intact Cells by Conduritol B-Epoxide

\begin{tabular}{|c|c|c|c|c|c|c|}
\hline \multirow[b]{2}{*}{ Cell type } & \multicolumn{2}{|c|}{$\begin{array}{l}\text { Activity } \mathrm{nmol} / \mathrm{h} \text { per } \\
\mathrm{mg} \text { protein in } \\
\text { nonpreincubated } \\
\text { cells }\end{array}$} & \multicolumn{4}{|c|}{$\begin{array}{l}\text { CBE-inhibitable activity (percent } \\
\text { of that in nonpreincubated cells) } \\
\text { after preincubation with CBE for }\end{array}$} \\
\hline & $-\mathrm{CBE}$ & $+\mathrm{CBE}$ & 10 & 20 & 40 & 60 \\
\hline & & & \multicolumn{4}{|c|}{$\min$} \\
\hline \multicolumn{7}{|l|}{ Fibroblasts } \\
\hline Control & 384.2 & 1.0 & 80 & 66 & 45 & 30 \\
\hline $370 / 370$ & 37.8 & 0.7 & 95 & 87 & 79 & 68 \\
\hline $370 / 444$ & 20.7 & 0.7 & 90 & 81 & 64 & 52 \\
\hline $444 / 444$ & 17.2 & 0.4 & 82 & 69 & 48 & 32 \\
\hline \multicolumn{7}{|c|}{ Lymphoblasts } \\
\hline Control & 17.1 & 0.4 & 75 & 55 & 29 & 16 \\
\hline $370 / 370$ & 1.5 & 0.3 & 80 & 63 & 32 & 21 \\
\hline $370 / 444$ & 1.2 & 0.3 & 78 & 59 & 33 & 17 \\
\hline
\end{tabular}

Cells grown in RPMI 1640 culture medium containing $10 \%$ (by volume) FCS with $5 \% \mathrm{CO}_{2}$ in the gas phase were incubated at $37^{\circ} \mathrm{C}$ with $100 \mu \mathrm{M} \mathrm{CBE}$ for different periods of time, washed extensively at $4^{\circ} \mathrm{C}$ with PBS to remove excess inhibitor and harvested. Next, the cells were homogenized in $50 \mathrm{mM}$ potassium phosphate, $\mathrm{pH} 6.5$, containing $0.25 \%$ (by volume) Triton X-100. $\beta$-Glucosidase activity was measured with $5 \mathrm{mM} 4-\mathrm{MU}-\beta$-glucoside as substrate in 100:200 $\mathrm{mM}$ citric acid/sodium phosphate (pH 5.2) containing $0.1 \%$ (by volume) Triton X-100 and $0.2 \%$ (mass/vol) sodium taurocholate. At each preincubation time point, enzyme activity was measured in the presence of $1 \mathrm{mM} \mathrm{CBE}$ in one sample and in the absence of CBE in a parallel sample. Enzyme activity was related to total cellular protein. The CBE-inhibitable enzymic activity at each time point is expressed as percentage of that in cells not preincubated with inhibitor. The results of a typical experiment are shown. Analogous results were obtained in at least three independent experiments. $370,{ }^{370}$ Asn $\rightarrow$ Ser allele; $444,{ }^{444} \mathrm{Leu} \rightarrow$ Pro allele.

a control subject and a patient with the genotype ${ }^{370}$ Asn $\rightarrow$ Ser $/{ }^{444}$ Leu $\rightarrow$ Pro. Quantification of the differently sized gold particles in lysosomes shows that the ratio of labeled activator protein to labeled glucocerebrosidase is not significantly different in fibroblasts and lymphoblasts of the control subject and the Gaucher disease patient ( Table IV). The amount of activator protein was also quantified by means of a functional test in which the ability of denatured protein preparations from different cell types to activate purified glucocerebrosidase was measured. As shown in Table $\mathrm{V}$, the amount of activator protein was greater in fibroblasts than in lymphoblasts, but there was no difference between control and Gaucher fibroblasts, or between control and Gaucher lymphoblasts. Thus, the apparent difference in properties of glucocerebrosidase in lymphoblasts and fibroblasts from patients with ${ }^{370} \mathrm{Asn} \rightarrow$ Ser glucocerebrosidase cannot simply be attributed to a higher amount of intralysosomal activator protein in the lysosomes of the former cells.

Effect of pH on activity of ${ }^{370}$ Asn $\rightarrow$ Ser glucocerebrosidase Pure enzyme. The influence of $\mathrm{pH}$ on enzymic activity of purified splenic ${ }^{370} \mathrm{Asn} \rightarrow$ Ser glucocerebrosidase and control enzyme was studied using acetate and citric acid/sodium phosphate buffers in the pH range 4.0-6.0. Fig. $4 \mathrm{~A}$ shows that the activity of ${ }^{370} \mathrm{Asn} \rightarrow$ Ser glucocerebrosidase in the presence of activator protein and phospholipid has a very sharp $\mathrm{pH}$ optimum. At $\mathrm{pH}$ values $>5.4$ in acetate buffer and $>5.2$ in citric acid/sodium phosphate buffer, the mutated enzyme is markedly reduced in specific activity. It was noted that in the presence of higher amounts of activator protein, the specific activity of ${ }^{370} \mathrm{Asn} \rightarrow$ Ser glucocerebrosidase was also close to normal at $\mathrm{pH}$ values between 4.3 and 5.0, but not at $\mathrm{pH}$ values $>5.0$ (not shown; see also [17]). It appears that the ${ }^{370}$ Asn $\rightarrow$ Ser substitution in glucocerebrosidase leads to an increased $\mathrm{pH}$ dependency of the enzyme with respect to activation by activator protein. Particularly at higher $\mathrm{pH}$ values, the mutated enzyme is poorly activated by saposin. Fig. $4 B$ shows that also the reactivity of ${ }^{370} \mathrm{Asn} \rightarrow$ Ser glucocerebrosidase with $\mathrm{CBE}$ is extraordinarily $\mathrm{pH}$ dependent in the presence of activator protein and phospholipid. At higher $\mathrm{pH}$ values, the mutated enzyme is dramatically less sensitive for CBE-induced inactivation compared to control enzyme.

Similar results to those presented in Fig. 4 were obtained with enzyme isolated from fibroblasts and lymphoblasts from patients homozygous for the ${ }^{370} \mathrm{Asn} \rightarrow$ Ser allele. Furthermore, ${ }^{370}$ Asn $\rightarrow$ Ser glucocerebrosidase isolated from 3T3 fibroblasts transfected with site-directed mutagenized human glucocerebrosidase cDNA (15) showed a comparable pH dependency (not shown).

Manipulation of intralysosomal $p H$ with weak bases. Intact fibroblasts and lymphoblasts were exposed to $\mathrm{NH}_{4} \mathrm{Cl}$, a weak base, to increase the intralysosomal $\mathrm{pH}$, as described by $\mathrm{Oh}$ kuma and Poole (34). These authors have shown that in mouse macrophages addition of increasing concentrations of $\mathrm{NH}_{4} \mathrm{Cl}$ leads to a concomitant increase in $\mathrm{pH}$ of intracellular acidic compartments (including lysosomes), as monitored by the extent of quenching of the fluorescence of endocytosed dextran-fluorescein isothiocyanate. For instance, on addition of $10 \mathrm{mM} \mathrm{NH}_{4} \mathrm{Cl}$, the $\mathrm{pH}$ of such compartments increases from $\sim 4.8$ to $\sim 6.2$. Fig. 5 shows that with increasing amounts of $\mathrm{NH}_{4} \mathrm{Cl}$, glucocerebrosidase in cells becomes less sensitive to inactivation by $\mathrm{CBE}$, as would be expected from the results of Fig. $4 \mathrm{~B}$. This effect of $\mathrm{NH}_{4} \mathrm{Cl}$ is reversible (not shown). It should be noted that in the absence of $\mathrm{NH}_{4} \mathrm{Cl}$ glucocerebrosidase is much more effectively inactivated by $\mathrm{CBE}$ in Gaucher disease lymphoblasts than in Gaucher disease fibroblasts. However, at increasing concentrations of $\mathrm{NH}_{4} \mathrm{Cl}$, the rate of inactivation of glucocerebrosidase in lymphoblasts resembles that in fibroblasts from the same Gaucher disease patient. Similar observations were made using methylamine (not shown).

The findings presented in Figs. 4 and 5 suggest that the intralysosomal $\mathrm{pH}$ to which glucocerebrosidase is exposed might on the average be lower in cultured lymphoblasts than in fibroblasts. As an approximate measure of the $\mathrm{pH}$ in lysosomes (and other acidic compartments), we measured the accumulation of radioactively labeled weak base chloroquine (35). We observed that about seven times more radioactively labeled chloroquine was trapped by lymphoblasts than by fibroblasts when related to the amount of glucocerebrosidase present in the two cell types, whereas the immunogold labeling studies suggest that the concentration of glucocerebrosidase is about twice as high in lysosomes of fibroblasts than of lymphoblasts (see Table IV). This suggests that the average intralysosomal $\mathrm{pH}$ is higher in fibroblasts than in lymphoblasts.

Assessment of activation state of glucocerebrosidase. When control cells are homogenized in detergent-free buffer, a pro- 

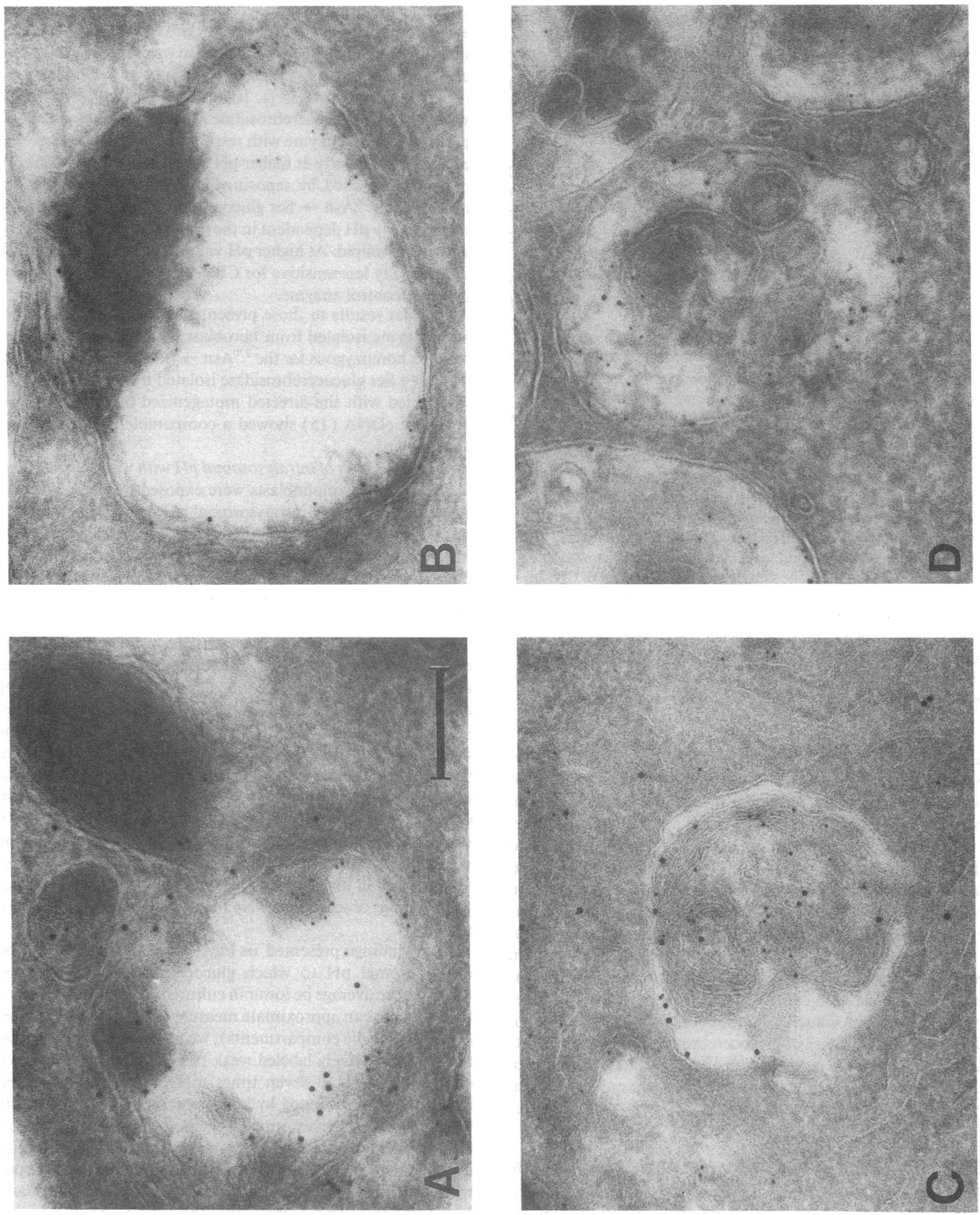
Table IV. Quantification of Gold Labeling of Glucocerebrosidase and Saposin C in Lysosomal Structures in Fibroblasts and Lymphoblasts from a Control Subject and a Type 1 Gaucher Patient

\begin{tabular}{|c|c|c|c|c|c|c|c|}
\hline \multirow[b]{2}{*}{ Cell line } & \multirow[b]{2}{*}{ Antigen } & \multicolumn{3}{|c|}{ Number of gold particles/lysosome in fibroblasts } & \multicolumn{3}{|c|}{ Number of gold particles/lysosome in lymphoblasts } \\
\hline & & Mean \pm SEM & $n$ & Range & Mean \pm SEM & $n$ & Range \\
\hline \multirow[t]{3}{*}{ Control } & $\beta$-Glu & $8.1 \pm 1.2$ & 44 & $0-34$ & $3.9 \pm 0.5$ & 83 & $0-31$ \\
\hline & Saposin C & $11.6 \pm 2.1$ & 43 & $0-51$ & $5.4 \pm 0.7$ & 84 & $0-30$ \\
\hline & Saposin $C / \beta$-Glu & $1.61 \pm 0.28$ & 38 & $0-9$ & $2.00 \pm 0.37$ & 69 & $0-18$ \\
\hline \multirow[t]{3}{*}{ Gaucher } & $\beta$-Glu & $6.0 \pm 0.9$ & 20 & $0-15$ & $2.5 \pm 0.7$ & 33 & $0-16$ \\
\hline & Saposin C & $9.1 \pm 1.4$ & 20 & $1-22$ & $5.8 \pm 1.0$ & 33 & $0-29$ \\
\hline & Saposin $C / \beta$-Glu & $2.04 \pm 0.43$ & 19 & $0-7$ & $2.98 \pm 1.10$ & 25 & $0-29$ \\
\hline
\end{tabular}

For experimental details, see the legend to Fig. 3. Lysosomal structures present in electron micrographs of a typical immunolabeling experiment were quantified. The number of lysosomal structures analysed is indicated in the table. $\beta$-Glu, glucocerebrosidase.

portion of glucocerebrosidase remains in activated form, as reflected by a high ratio of enzymic activity measured in the absence of additional activators compared to that measured in the presence of taurocholate ( any original activation of glucocerebrosidase and activates fully all enzymes present (23). Table VI shows that the activity in the absence of activator is relatively higher in a homogenate of lymphoblasts than that in a homogenate of fibroblasts. When the cells are pretreated with $\mathrm{NH}_{4} \mathrm{Cl}$ to increase the $\mathrm{pH}$ of intracellular acidic compartments (see above), this difference disappears and glucocerebrosidase is only poorly active in the absence of additional activator in homogenates from both cell types. This finding supports the assumption that on the average, glucocerebrosidase is present in a more activated state in intact lymphoblasts than in fibroblasts because of an intralysosomal $\mathrm{pH}$ difference.

\section{Discussion}

The properties of the ${ }^{370} \mathrm{Asn} \rightarrow$ Ser glucocerebrosidase in vitro are intriguing: Under most assay conditions, this mutated enzyme is impaired in activity towards substrate. However, in the presence of the natural activator protein saposin $\mathrm{C}$ and phosphatidylserine, the enzyme functions in a near normal fashion at an appropriate acidic $\mathrm{pH}$. To obtain information on the properties of this mutated enzyme in situ, the irreversible inhibitor CBE has been used, an approach that was developed and used previously by other investigators $(25,36,37)$. Although it is obvious that the reaction of glucocerebrosidase with $\mathrm{CBE}$ involves only part of the total reaction mechanism of substrate hydrolysis (discussed in more detail in [2]), analysis of CBEinduced inactivation of glucocerebrosidase is informative because the reactivity of (mutant) glucocerebrosidase with CBE appears to reflect to a large extent the ability of enzyme to be active towards substrate.
Some of our findings are consistent with those of earlier studies. First, it has been reported by Grabowski and coworkers $(36,37)$ that the mutant form of glucocerebrosidase in Ashkenazi Jewish type 1 Gaucher disease patients referred to as group B mutant enzyme is less efficiently inactivated by CBE than control enzyme either in fibroblast extracts or in partially purified splenic preparations. It is now almost certain that group B mutant enzyme is identical to the ${ }^{370} \mathrm{Asn} \rightarrow$ Ser glucocerebrosidase (2). Second, it has been reported that glucocerebrosidase in intact fibroblasts from Ashkenazi Jewish Gaucher disease type 1 patients was less efficiently inactivated by CBE compared to enzyme in cells from control subjects and from other Gaucher disease patients (36). Thus, in the studies cited above, particular stress was laid upon the ethnic background of type 1 Gaucher disease patients. We have found that the rate of inactivation of glucocerebrosidase by CBE in fibroblasts from

Table V. Level of Activator Protein (Saposin C) in Fibroblasts and Lymphoblasts from a Control Subject and a Type 1 Gaucher Patient

\begin{tabular}{llc}
\hline \multicolumn{1}{c}{ Cell type } & \multicolumn{1}{c}{ Cell line } & Activator \\
\hline \multirow{3}{*}{ Fibroblasts } & & $U /$ mg protein \\
& Control & 0.58 \\
Lymphoblasts & Type 1 Gaucher & 0.53 \\
& Control & 0.21 \\
& Type 1 Gaucher & 0.26
\end{tabular}

Cell extracts were boiled for 5 min, centrifuged, and the supernatants were tested for their capacity to stimulate the enzymic activity of purified placental glucocerebrosidase as described (12). $1 \mathrm{U}$ of activation is defined as the amount of activator protein that stimulates the activity of glucocerebrosidase by a factor of 100 .

Figure 3. Immunocytochemical visualisation of glucocerebrosidase and saposin C. Fibroblasts and lymphoblasts of a control subject and a Gaucher disease type 1 patient heterozygous for the ${ }^{370} \mathrm{Asn} \rightarrow$ Ser and ${ }^{444} \mathrm{Leu} \rightarrow$ Pro glucocerebrosidase substitutions were washed in PBS, fixed, cryosectioned and processed for immunogold double labeling as described (33). The immunoglobulins were visualized with protein A conjugated with 10-nm gold particles (antiglucocerebrosidase) and with protein A conjugated with 5-nm gold particles (anti-saposin C). Identical results were obtained when glucocerebrosidase was visualized with a 5-nm gold probe and the activator protein was visualized with a 10-nm gold probe. $(A)$ Fibroblasts of the control subject; $(B)$ fibroblasts of the Gaucher patient; $(C)$ lymphoblasts of the control subject; and $(D)$ lymphoblasts of the Gaucher patient. Bar, $0.2 \mu \mathrm{m}$. 

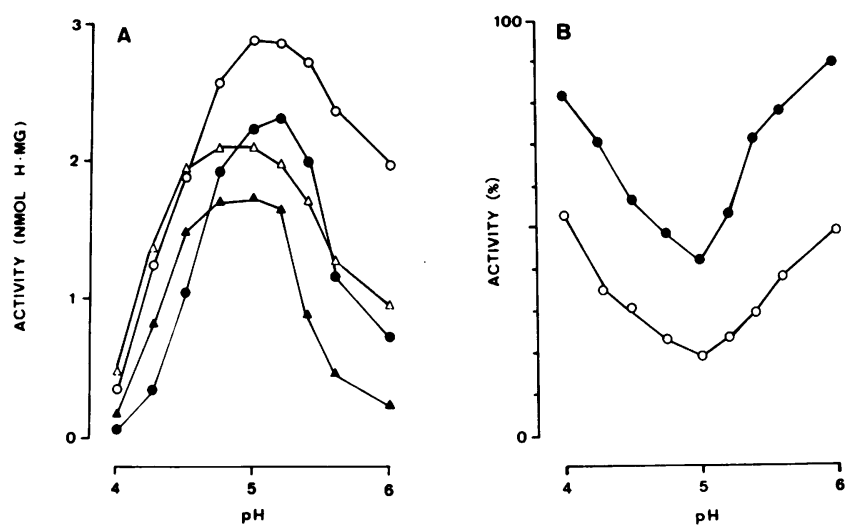

Figure 4. Influence of $\mathrm{pH}$ on the properties of ${ }^{370} \mathrm{Asn} \rightarrow$ Ser glucocerebrosidase, purified from spleen. The effect of $\mathrm{pH}$ on the properties of immunoaffinity purified control and ${ }^{370} \mathrm{Asn} \rightarrow$ Ser glucocerebrosidase in the presence of $10 \mu \mathrm{g} / \mathrm{ml}$ phosphatidylserine and $2.4 \mu \mathrm{g} / \mathrm{ml}$ saposin $\mathrm{C}$ was determined. $(A)$ The activity of glucocerebrosidase was determined with $5 \mathrm{mM} 4-\mathrm{MU}-\beta$-glucoside as substrate in the presence of $50 \mathrm{mM}$ acetate buffer $(\circ, \bullet)$ or $50: 100 \mathrm{mM}$ citric acid/sodium phosphate buffer $(\Delta, \Delta)$ varying in $\mathrm{pH}$ from 4.0 to 6.0. $O$ and $\Delta$, control; $\bullet$ and $\Delta,{ }^{370}$ Asn $\rightarrow$ Ser $/{ }^{370}$ Asn $\rightarrow$ Ser. $(B)$ The inactivation of glucocerebrosidase by CBE was determined in $50: 100 \mathrm{mM}$ citric acid/sodium phosphate buffer ( $\mathrm{pH}$ range 4.0-6.0). Enzyme activity was determined as described in the legend of Fig. 1. ०, Control; ๑, ${ }^{370}$ Asn $\rightarrow$ Ser $/{ }^{370}$ Asn $\rightarrow$ Ser.

${ }^{370}$ Asn $\rightarrow$ Ser $/{ }^{370}$ Asn $\rightarrow$ Ser patients and, to a lesser extent, in fibroblasts from the more frequently encountered patients heterozygous for this mutation, is slow. However, we were not able to distinguish type 1 Gaucher disease patients with Ashkenazi Jewish background from patients with non-Jewish background on the basis of CBE-induced inactivation.

During this study, the important observation was made that the activation state of glucocerebrosidase in the lysosomes as measured in situ differs in fibroblasts and lymphoblasts. This finding substantiates earlier studies carried out with homogenates from the two cell types (23). The cell-type-specific difference is particularly evident in the case of ${ }^{370}$ Asn $\rightarrow$ Ser
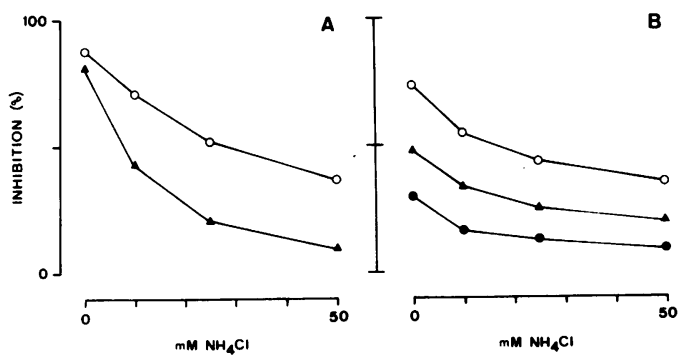

Figure 5. Influence of ammonia on inactivation of glucocerebrosidase in intact cells by conduritol B-epoxide. Cells were preincubated for 30 min at $37^{\circ} \mathrm{C}$ in culture medium containing different concentrations of $\mathrm{NH}_{4} \mathrm{Cl}$. Next, $100 \mu \mathrm{M} \mathrm{CBE}$ was added to the medium and the cells were harvested immediately or $1 \mathrm{~h}$ later. Glucocerebrosidase activity per milligram total cellular protein was determined as described in the legend to Table III. The results of a typical experiment are shown. Similar results were obtained in at least two independent experiments. ( $A$ ) Lymphoblasts; $(B)$ fibroblasts. $\bigcirc$, Control; $\bullet$, ${ }^{370}$ Asn $\rightarrow$ Ser $/{ }^{370}$ Asn $\rightarrow$ Ser; $\triangle,{ }^{370}$ Asn $\rightarrow$ Ser $/{ }^{444}$ Leu $\rightarrow$ Pro.
Table VI. Activation State of Glucocerebrosidase in Homogenates of Control Cells

\begin{tabular}{|c|c|c|c|c|}
\hline \multirow[b]{2}{*}{ Cell type } & \multirow[b]{2}{*}{$\begin{array}{l}\text { Cells preincubated } \\
\text { for } 30 \text { min with }\end{array}$} & \multicolumn{3}{|c|}{$\begin{array}{l}\text { Glucocerebrosidase activity } \\
\text { in homogenate with }\end{array}$} \\
\hline & & $\begin{array}{l}\text { No additions } \\
\text { (A) }\end{array}$ & $\begin{array}{c}\text { Taurocholate/Triton } \\
\text { X-100 (B) }\end{array}$ & $\mathrm{A} / \mathrm{B}$ \\
\hline & & \multicolumn{3}{|c|}{$\mathrm{nmol} / \mathrm{h}$} \\
\hline \multirow[t]{2}{*}{ Fibroblasts } & No additions & 79.6 & 153.2 & 0.52 \\
\hline & $25 \mathrm{mM} \mathrm{NH}_{4} \mathrm{Cl}$ & 57.2 & 159.1 & 0.36 \\
\hline \multirow[t]{2}{*}{ Lymphoblasts } & No additions & 10.0 & 14.1 & 0.71 \\
\hline & $25 \mathrm{mM} \mathrm{NH}_{4} \mathrm{Cl}$ & 5.3 & 13.9 & 0.38 \\
\hline
\end{tabular}

Cells were harvested, washed in PBS and homogenized in 10:20 mM citric acid/sodium phosphate buffer, $\mathrm{pH} 4.0$, by brief sonication. Enzyme activity was measured in two reaction mixtures. The reaction mixture without an added activator contained 100:200 mM citric acid/sodium phosphate, $\mathrm{pH} 4.0$, and $5 \mathrm{mM} 4-\mathrm{MU}-\beta$-glucoside. The other reaction mixture contained 100:200 mM citric acid/sodium phosphate, $\mathrm{pH} 5.2,0.1 \%$ (by volume) Triton X-100 and $0.2 \%$ (mass/ vol) sodium taurocholate as activators, and $5 \mathrm{mM} 4-\mathrm{MU}-\beta$-glucoside. Assays were performed in the absence and presence of $1 \mathrm{mM} \mathrm{CBE}$ to determine the contribution of glucocerebrosidase to the total $\beta$ glucosidase activity. The results of a typical experiment are given. Similar results were obtained in two other independent experiments.

glucocerebrosidase, the catalytic properties of which are so strongly determined by the state of activation of the enzyme.

Our studies suggest that the intralysosomal $\mathrm{pH}$ determines the state of activation of glucocerebrosidase. Again, this is particularly relevant for ${ }^{370} \mathrm{Asn} \rightarrow$ Ser glucocerebrosidase: the activation of this mutant enzyme by activator protein is extraordinarily $\mathrm{pH}$ sensitive. Thus, a cell-type-specific difference in intralysosomal $\mathrm{pH}$ could explain the difference in properties of ${ }^{370} \mathrm{Asn} \rightarrow$ Ser glucocerebrosidase in intact fibroblasts and lymphoblasts. Moreover, variability between individuals in intralysosomal conditions may underlie the heterogeneity in severity of the clinical expression of Gaucher disease in individuals with the same glucocerebrosidase genotype. In this connection, it is of interest to mention that some homozygotes for the ${ }^{370}$ Asn $\rightarrow$ Ser glucocerebrosidase mutation are not or only very mildly affected clinically $(8,38)$, and that a strict correlation between glucocerebrosidase genotype and Gaucher disease clinical phenotype has not always been noted; e.g., see reference 39. In Gaucher disease, glucocerebroside accumulation is restricted to macrophage-like cells. It will, therefore, be of interest to establish the intralysosomal $\mathrm{pH}$ and the state of activation of glucocerebrosidase in macrophages from patients with different degrees of severity of the clinical manifestation. Such studies are underway.

\section{Acknowledgments}

We are most grateful to Ms. Betty Brouwer-Kelder, Marinella van Leeuwen, and Anneke Strijland for their excellent technical assistance, and to Dr. M. Horowitz and Dr. E. M. Petersen for providing us with fibroblast and EBV-lymphoblast cell lines. Furthermore, we would like to thank Dr. G. Schwarzmann for his generous gift of $\mathrm{C}_{6}-\mathrm{NBD}$ glucosylceramide. We thank Ms. Wendy van Noppen and Elsbeth Vlugt-van Daalen for their help in the preparation of the manuscript.

This work was supported by generous grants from The National Gaucher Foundation, U.S.A. (grant number NGF 17), and the Junta 
Nacional de Investigacao Cientifica e Technologica, Portugal (grant number 87388). J. M. F. G. Aerts is an Established Investigator of the Royal Netherlands Academy of Sciences.

\section{References}

1. Barranger, J. A., and E. I. Ginns. 1989. Glucosylceramide lipidosis: Gaucher disease. In The Metabolic Basis of Inherited Disease. C. R. Scriver, A. L. Beaudet, W. S. Sly, and D. Valle, editors. McGraw-Hill Inc., NY. 1677-1698.

2. Grabowski, G. A., S. Gatt, and M. Horowitz. 1990. Acid $\beta$-glucosidase: enzymology and molecular biology of Gaucher disease. Crit. Rev. Biochem. Mol. Biol. 25:385-414.

3. Hong, C. M., T. Ohashi, X. J. Yu, S. Weiler, and J. A. Barranger. 1990 Sequence of two alleles responsible for Gaucher disease. DNA Cell Biol. 9:233241.

4. Latham, T., B. D. M. Theophilus, G. A. Grabowski, and F. I. Smith. 1991 Heterogeneity of mutations in the acid beta-glucosidase gene of Gaucher disease patients. DNA Cell Biol. 10:15-21.

5. Beutler, E., T. Gelbart, W. Kuhl, A. Zimran, and C. West. 1992. Mutations in Jewish patients with Gaucher disease. Blood. 79:1662-1666.

6. Beutler, E. 1992. Gaucher disease: New molecular approaches to diagnosis and treatment. Science (Wash. DC). 256:794-799.

7. Tsuji, S., P. V. Choudary, B. M. Martin, B. K. Stubblefield, J. A. Mayor J. A. Barranger, and E. I. Ginns. 1987. A mutation in the human glucocerebrosidase gene in neuronopathic Gaucher's disease. N. Engl. J. Med. 316:570-575.

8. Zimran, A., E. Gross, C. West, J. Sorge, M. Kubitz, and E. Beutler. 1989 Prediction of severity of Gaucher's disease by identification of mutations at DNA level. Lancet. 8659:349-352.

9. Sorge, J., C. West, B. Westwood, and E. Beutler. 1985. Molecular cloning and nucleotide sequence of the human glucocerebrosidase gene. Proc. Natl. Acad. Sci. USA. 82:7289-7293.

10. Tsuji, S., B. M. Martin, J. A. Barranger, B. K. Stubblefield, M. E. LaMarca, and E. I. Ginns. 1988. Genetic heterogeneity in type 1 Gaucher disease multiple genotypes in Ashkenazic and non-Ashkenazic individuals. Proc. Natl Acad. Sci. USA. 85:2349-2352.

11. Theophilus, B., T. Latham, G. A. Grabowski, and F. I. Smith. 1989. Gaucher disease: molecular heterogeneity and phenotype-genotype correlations Am. J. Hum. Genet. 45:212-225.

12. Aerts, J. M. F. G., W. E. Donker-Koopman, S. Brul, S. van Weely, M. C. Sa Miranda, J. A. Barranger, J. M. Tager, and A. W. Schram. 1990. Comparative study on glucocerebrosidase in spleens from patients with Gaucher disease. Biochem. J. 269:93-100.

13. Van Weely, S., M. B. van Leeuwen, I. D. C. Jansen, M. A. C. de Bruyn, E. M. Brouwer-Kelder, A. W. Schram, M. C. Sa Miranda, J. A. Barranger, E. M Petersen, J. Goldblatt, et al. 1991. Clinical phenotype of Gaucher disease in relation to properties of mutant glucocerebrosidase in cultured fibroblasts. Bio chim. Biophys. Acta. 1096:301-311.

14. Grace, M. E., P. N. Graves, F. I. Smith, and G. A. Grabowski. 1990 Analyses of catalytic activity and inhibitor binding of human acid $\beta$-glucosidase by site-directed mutagenesis. Identification of residues critical to catalysis and evidence for causality of two Ashkenazi Jewish Gaucher disease type 1 mutations. J. Biol. Chem. 265:6827-6835.

15. Ohashi, T., C. M. Hong, S. Weiler, J. Tomich, J. Aerts, J. Tager, and J. Barranger. 1991. Characterization of human glucocerebrosidase from different mutant alleles. J. Biol. Chem. 266:3661-3667.

16. O'Brien, J. S., and Y. Kishimoto. 1991. Saposin proteins: structure, function, and role in human lysosomal storage disorders. FASEB (Fed. Am. Soc. Exp. Biol.) J. 5:301-308.

17. Aerts, J. M. F. G., M. C. Sa Miranda, E. Brouwer-Kelder, S. van Weely, J. A. Barranger, and J. M. Tager. 1990. Conditions affecting the activity of glucocerebrosidase purified from spleens of control subjects and patients with type Gaucher disease. Biochim. Biophys. Acta. 1041:55-63.

18. Masuno, M., S. Tomatsu, K. Sukegawa, and T. Orii. 1990. Non-existence of a tight association between $\mathrm{a}^{444}$ leucine to proline mutation and phenotypes of Gaucher disease: high frequency of a Ncil polymorphism in the nonneuronopathic form. Hum. Genet. 84:203-206.

19. Dahl, N., M. Lagerström, A. Erikson, and U. Pettersson. 1990. Gaucher disease type III (Norrbottnian type) is caused by a single mutation in exon 10 of the glucocerebrosidase gene. Am. J. Hum. Genet. 47:275-278.
20. Glew, R. H., V. Gopalan, C. A. Hubbell, E. Beutler, J. D. Geil, and R. E. Lee. 1991. A case of nonneurologic Gaucher's disease that biochemically resembles the neurologic types. J. Neuropathol. \& Exp. Neurol. 50:108-117.

21. Grace, M. E., A. Berg, G. He, L. Goldberg, M. Horowitz, and G. A. Grabowski. 1991. Gaucher disease: Heterologous expression of two alleles associated with neuronopathic phenotypes. Am. J. Hum. Genet. 49:646-655.

22. Beutler, E., T. Gelbart, W. Kuhl, J. Sorge, and C. West. 1991. Identification of the second common Jewish Gaucher disease mutation makes possible population-based screening for the heterozygous state. Proc. Natl. Acad. Sci. USA. 88:10544-10547.

23. Sa Miranda, M. C., J. M. F. G. Aerts, R. Pinto, S. van Weely, J. A. Barranger, and J. M. Tager. 1990. Activity of glucocerebrosidase in extracts of different cell types from type 1 Gaucher disease patients. Clin. Genet. 38:218 227.

24. Legler, G. 1988. Beta-glucocerebrosidase: mechanistic studies with covalent and non-covalent inhibitors. In Lipid Storage Disorders. Biological and Biomedical Aspects. R. Salvayre, L. Douste-Blazy, and S. Gatt, editors. Plenum Press, NY. 63-72.

25. Bieberich, E., and G. Legler. 1989. Intracellular activity of lysosomal glucosylceramidase measured with 4-nonylumbelliferyl $\beta$-glucoside. Biol. Chem. Hoppe-Seyler. 370:809-817.

26. Firon, N., N. Eyal, E. H. Kolodny, and M. Horowitz. 1990. Genotype assignment in Gaucher disease by selective amplification of the active glucocerebrosidase gene. Am. J. Hum. Genet. 46:527-532.

27. Aerts, J. M. F. G., W. E. Donker-Koopman, M. K. van der Vliet, L. M. V. Jonsson, E. I. Ginns, G. J. Murray, J. A. Barranger, J. M. Tager, and A. W. Schram. 1985. The occurrence of two immunologically distinguishable $\beta$-glucocerebrosidases in human spleen. Eur. J. Biochem. 150:565-574.

28. Ginns, E. I., R. O. Brady, S. Pirruccello, C. Moore, S. Sorrell, F. S. Furbish, G. J. Murray, J. Tager, and J. A. Barranger. 1982. Mutations of glucocerebrosidase: discrimination of neurologic and non-neurologic phenotypes of Gaucher disease. Proc. Natl. Acad. Sci. USA. 79:5607-5610.

29. Fujibayashi, S., and D. A. Wenger. 1985. Synthesis and processing of sphingolipid activator protein-2 (SAP-2) in cultured human skin fibroblasts Clin. Chim. Acta. 146:147-156.

30. Aerts, J. M. F. G., W. E. Donker-Koopman, G. J. Murray, J. A. Barranger, J. M. Tager, and A. W. Schram. 1986. A procedure for the rapid purification in high yield of human glucocerebrosidase using immunoaffinity chromatography with monoclonal antibodies. Anal. Biochem. 154:655-663.

31. Aerts, J. M. F. G., W. E. Donker-Koopman, C. van Laar, S. Brul, G. J. Murray, D. A. Wenger, J. A. Barranger, J. M. Tager, and A. W. Schram. 1987 Relationship between the two immunologically distinguishable forms of glucocerebrosidase in tissue extracts. Eur. J. Biochem. 163:583-589.

32. Lowry, O. H., N. J. Rosebrough, A. L. Farr, and R. J. Randall. 1951. Protein measurement with the Folin phenol reagent. J. Biol. Chem. 193:265275.

33. Wiemer, E. A. C., S. Brul, W. H. Just, R. van Driel, E. Brouwer-Kelder, M. van den Berg, P. J. Weijers, R. B. H. Schutgens, H. van den Bosch, A. W. Schram, et al. 1989. Presence of peroxisomal membrane proteins in liver and fibroblasts from patients with the Zellweger syndrome and related disorders: evidence for the existence of peroxisomal ghosts. Eur. J. Cell Biol. 50:407-417.

34. Ohkuma, S., and B. Poole. 1978. Fluorescence probe measurement of the intralysosomal $\mathrm{pH}$ in living cells and the perturbation of $\mathrm{pH}$ by various agents. Proc. Natl. Acad. Sci. USA. 75:3327-3331.

35. Hollemans, M., R. P. J. Oude Elferink, P. G. de Groot, A. Strijland, and J. M. Tager. 1981. Accumulation of weak bases in relation to intralysosomal $\mathrm{pH}$ in cultured human skin fibroblasts. Biochim. Biophys. Acta. 643:140-151.

36. Grabowski, G. A., T. Dinur, K. M. Osiecki, J. R. Kruse, G. Legler, and S. Gatt. 1985. Gaucher disease types 1, 2, and 3: differential mutations of the acid $\beta$-glucosidase active site identified with conduritol B epoxide derivatives and sphingosine. Am. J. Hum. Genet. 37:499-510.

37. Grabowski, G. A., K. Osiecki-Newman, T. Dinur, D. Fabbro, G. Legler, S. Gatt, and R. J. Desnick. 1986. Human acid $\beta$-glucosidase: use of conduritol B epoxide derivatives to investigate the catalytically active normal and Gaucher disease enzymes. J. Biol. Chem. 261:8263-8269.

38. Zimran, A., T. Gelbart, B. Westwood, G. A. Grabowski, and E. Beutler. 1991. High frequency of the Gaucher disease mutation at nucleotide 1226 among Ashkenazi Jews. Am. J. Hum. Genet. 49:855-859.

39. Sidransky, E., S. Tsuji, B. M. Martin, B. Stubblefield, and E. I. Ginns. 1992. DNA mutation analysis of Gaucher patients. Am. J. Med. Genet. 42:331336. 